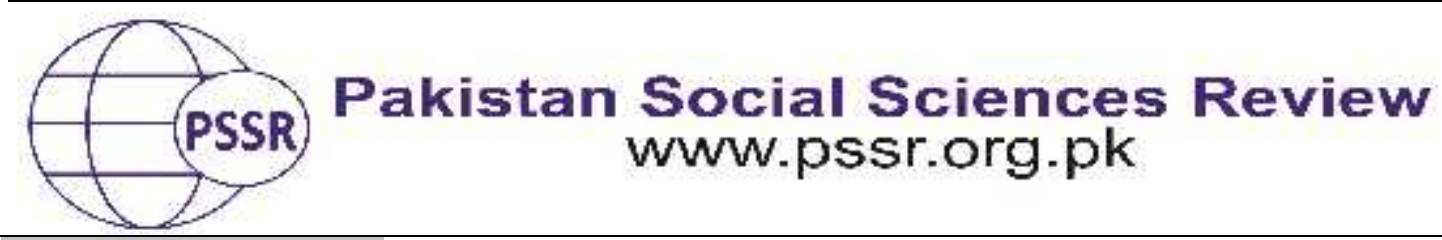

RESEARCH PAPER

\title{
Family School Partnership: A Cohesive Perception of Teachers and Parents
}

\author{
Dr. Farah Deeba* ${ }^{1}$ Dr. Haji Karim Khan ${ }^{2}$ Amna Saleem ${ }^{3}$
}

1. Assistant Professor, Department of Education, Bahauddin Zakariya University, Multan, Punjab, Pakistan

2. University of Baltistan, Skardu, Gilgit- Baltistan, Pakistan

3. Lecturer, Department of Education, The Women University, Multan, Punjab, Pakistan

\begin{tabular}{|c|c|}
\hline PAPER INFO & 月у \\
\hline $\begin{array}{l}\text { Received: } \\
\text { January } 29,2021 \\
\text { Accepted: } \\
\text { May } 01,2021 \\
\text { Online: } \\
\text { May } 15,2021\end{array}$ & $\begin{array}{l}\text { For the overall development of students, role of family and } \\
\text { school is noteworthy which helps them to cover all milestones in } \\
\text { their journey of success in education and learning. The core of } \\
\text { the survey was to investigate perceptions of teachers and } \\
\text { parents concerning family school partnership for which overall }\end{array}$ \\
\hline $\begin{array}{l}\text { Keywords: } \\
\text { Descriptive } \\
\text { Analysis, } \\
\text { Family School } \\
\text { Partnership, } \\
\text { Secondary } \\
\text { Schools }\end{array}$ & $\begin{array}{l}\text { enrolled in girls' secondary schools of district Multan were } \\
\text { selected by multistage sampling and further convenient } \\
\text { sampling procedure. To expose the perceptions of teachers and } \\
\text { parents, two different Likert type scales were administered } \\
\text { separately in which for parents a translated version was } \\
\text { administered. A descriptive analysis under Percentage and }\end{array}$ \\
\hline $\begin{array}{l}\text { *Corresponding } \\
\text { Author }\end{array}$ & $\begin{array}{l}\text { majority of items based on teachers perception was above } \\
\text { average and average which indicates teachers' strong agreement } \\
\text { for the items that they are agreed upon need of a strong FSP in } \\
\text { schools for enhanced level of success of students and parents' } \\
\text { cooperation is always welcomed in this regard. Parents also } \\
\text { agreed that family school partnership is common responsibility. } \\
\text { They showed consensus over having frequent meetings with } \\
\text { teachers to discuss problems of their children. They also } \\
\text { emphasized the need of establishing a collaborative and shared } \\
\text { work environment for FSP in schools. Schools should recognize } \\
\text { efforts made by teachers for successful partnership by involving } \\
\text { parents and community. Teachers and parents should be trained } \\
\text { for effective management of partnership practices }\end{array}$ \\
\hline
\end{tabular}

\section{Introduction}

All children belong to a family representing their social group and a community. Therefore, families and communities can play pivotal role in their lives. A family is an influential social group of any society and plays an imperative role in 
the learning and development of the children. Parents can play their crucial roles both at homes and in the schools in connection with the education of their children (Collier, Keefe, \& Hirrel, 2015).Undoubtedly, a family in the lives of children is the main source of their familiarity and interaction with the outside world. Families provide the young generations with opportunities to explore the world around and develop their repertoire of knowledge and skills as a result. Families provide platforms for the youngsters for their learning of languages, develop moral values, and enable them as confidant individuals to compete the future world. In other words, families are the central roots for the physical and psychological development of their children (Bryan, 2005).However, for the overall growth and development of children; families have to take assistance and support from school as well. On the other hand, schools also feel the need of respectful and collaborative association with families in form of a strong partnership that can be termed as Family School Partnership. Because they have to work together to create a conducive learning environment for children both where they live and where they learn for the active promotion of child's overall well-being (Ahmad, et. al, 2016).

Family school partnership is a child-focused approach in which families and educators cooperate, coordinate and collaborate for the multidimensional and diversified development of child covering his emotional, social, behavioral and academic spheres. Therefore, the bonding of family and school is highly important (Kim et al., 2012).This bonding is of utmost significance when students are in their transition period, when they exit their elementary level while entering at secondary level. Such partnerships put positive impacts on the students' academic achievements (Desforges \& Abouchar, 2003). Research has shown that all the schools which keep strong bonding with families and community, always produce high achieving students (Henderson \& Berla, 1994). In other words, when parents have high interest in the education of their children and are supported by school also then their children showcase improved achievements, getting high grades, having low rate absenteeism and showing least discipline problems (National PTA, 2012).

When families and schools work together in a trusting partnership, they lay the foundation for children's lifelong success. Because family school partnership has always been regarded as multifaceted approach that builds strong and effective relationship between schools, families and their communities to support learning. Effective and successful schools prefer to establish a strong partnership with their major stakeholder; the family while providing well designed, goal oriented and culturally responsive activities. The core of this partnership is to elevate performance and learning of students. In this way, FSP works as a learner-centred approach wherein families and educators join hand in hand to enhance success of a child across his social, emotional, moral, behavioural and academic domains emphasizing the need for bidirectional involvement by family and school (Kim et al., 2012).

Teachers as integral agents of this partnership, should enable themselves as mindful having awareness of broad spectrum of FSP. Services of these well aware teachers about importance of working with parents and getting along with multidimensional nature of FSP are always appreciated and recognized by school 
authorities and parents. However, research has found that teachers are not well prepared and trained to deal and manage with various practices and activities of FSP in their schools. The prime reasons of their inattentiveness and negligence towards FSP is time constraint as they have to complete their assignments of other course content and they are not taught any course manifesting FSP in their professional degree programs. On the other end, trained teachers perform partnership practices as being proactive and collaborative with parents (Willemse et al., 2018).

There is dire need to explore new, innovative, achievable and workable routes to establish strong and influential partnership between families and schools. Both family and teachers must serve as leading agents for nurturing the inherent potential of every child by uniting themselves into a unified whole that is school which serve as a platform for demonstrating potential and capabilities of students. In this paper, we have explored perceptions of teachers and parents about the family school relationships and its role in the education of the children. It is vital to know how the key stakeholders, parents and teachers construe the very notion of family school partnership and how they practice it. Exploring how parents and teachers perceive their roles as partners in the education of the children in Pakistan has yield contextually relevant findings. Therefore, findings have strong implications for policy makers, school systems and parents. The present study was conducted keeping in view to fulfil the objective of exploring and finding out the perception of teachers and parents regarding family school partnership. In schools of Pakistan, an organized system of FSP has yet not been found. Few private schools follow it but not as program and public schools also not fully equipped to deal it as a program. Partnership practices are not streamlined in all schools because there is no official guide is available. Some of the practices like parent teacher meetings and communication through social media and other modes of communication are followed by all schools but not in true spirit of partnership. In this scenario, such studies may provide a guideline by presenting international scenario which may capture attention of authorities to include courses promoting FSP practices in teacher training programs as well.

\section{Literature Review}

Family school partnerships are about all the collective endeavours, plans and activities carried out in collaboration of school staff, parents and other family members of the learners in schools. Exemplary partnerships are nested in mutual trust, respect and collaborative responsibility to take learning happen in schools. As the families are the first educators of their children and the schools also have an important role to nurture the children so as to prepare them as successful individuals. Therefore, the family school partnership is regarded vital in the education of the future generations (Semke \& Sheridan, 2011).

Family school partnership is linked with the enhanced academic performance, improved self-learning, improved discipline, improved inclination for doing homework appropriately, opting for healthy study habits, improved career 
orientation, enhanced positive attitudes and beliefs towards learning (Haack, 2007).Family school partnership becomes stronger and fruitful when both the school and families have shared goals. The shared vision, mission, values and goals between the parents and schools are needed for the greater adjustment of the learners. Thus, effective schools always value parents' involvement and encourage the parents to be part of the activities inside the schools. Such schools ensure partnerships through educating the parents about their roles in the partnerships. They arrange seminars, discussions, meetings and conferences with parents in this regard (Ferguson, 2004).

Spectrum of partnership practices have been grouped under various ways as types or dimensions. Catholic Education Office Melbourne (2013) has highlighted following dimensions of partnership on which building of FSP has to be constructed like family engagement and involvement in learning while connecting with school culture and community associates. On the other hand Department of Education, Skills and Employment, Australia (2008,p.5) has come up with developing the framework for FSP indicating these dimensions of FSP as need of " communicating, connecting learning at home and at school, building community and identity, recognizing the role of family, consultative decision making, collaborating beyond school and participating". Now its prime responsibility of teachers to set and develop activities under these dimensions. So that an influential FSP be possible in their schools.

In view of Epstein (2011) as cited in Willemse et al. (2018 p.255), "collaborating with parents is an inevitable core professional competency of teachers." However, FSP has been side lined as neglected area of concern by some schools and families rather taking it as catalytic agent for any school and development of students. While FSP orchestrate families and schools to bring about viable change in policies and practices needed to support children. The rising influence of FSP has robust implications for the teachers. Teachers' perceptions and behavioural tendencies are determinant in facilitating and fostering the partnership.

However, it is widely expressed by the teachers that their initial interaction with parents is always unsuccessful as they fail to engage them due to lack of training in this area (Mandarakas, 2014). Various research studies have exposed reasons of poor handling of FSP by the teachers as majority secondary school teachers are deprived of such skills that enable them to foster partnership with parents. Teacher training programs do not equip them with partnership practices as content courses are emphasized along with pedagogical skills. Social skills to deal with diversity of parents, family background and command over skills of assisting parents for preparing them to work with their children at home and preparing their children for self-learning and self-evaluation is missing in curricula of teacher training. Families also complaint that they do not receive necessary guidance about the ways to effectively involve themselves in their children's education and learning. Because teachers have lack of expertise in this area (Ferrara, 2017).Conversely, skilful and well-equipped teachers in the field of FSP demonstrate all their potential to play their allotted role and therefore, they are successful in establishing a stronger, 
healthy and joint partnership with parents and other community members (Mandarakas, 2014).

FSP works as a bridge, which has parents on its one end and teachers on the other end. Sometimes this unity is shaken due to non-cooperative behaviour of any one member as Martin (2017) found through her study that teachers feel themselves as devalued and their services were unappreciated by the parents. On the other hand, parents also complaint that they are taken for granted, unwelcomed and unrewarded by the school authorities and teachers which result in feeble connection between both stakeholders hindering support to success and well-being of students. This connection can be strong and successful when a school follows a documented policy in which an "Annual Action Plan" to move forward is mentioned covering all practices. This action plan focuses on establishing working policy with teacher training departments of higher education to get trained teachers to be recruited to effectively run and mange FSP practices. Furthermore, this plan should have schedule for celebrating and recognizing excellent efforts of parents and teachers by giving them awards and publicizing their efforts on media. Allocating generous budget, seeking feeding of parents and provision of training to teachers, heads and parents should be top priority policy of action plan (DESE, 2008).

Lonsdale and ACER (2008) recommend that all stakeholders should have consensus over growing need of partnership in school for which shared, realistic and achievable goals be set. Decision making should not be sole responsibility of any one party rather move among parents, teachers and community members. All stakeholders should fulfil their assigned responsibility for desired outcomes, students' productivity and increased family involvement by opting for developing learner centred practices and monitoring and reviewing targets. Thus the culmination of this partnership is mutual trust, respect and acceptance of common and shared responsibilities. This dream can come true through team work by all stakeholders (DESE, 2008).

Studies have highlighted that the family school partnership is often unseen in the middle and high schools, yet it showcases its existence through various means of communications. For instance, parents of secondary school students communicate through telephone calls and emails. They also read the school newsletters and browse through their websites. Furthermore, studies have found that family school partnership is not the same everywhere. Due to busy schedules, families usually face it difficult to manage their time to attend arranged activities in schools. Therefore, schools need to arrange programs for families so as to engage them through alternative ways of interactions (Leon, 2003).The American Association of School Administrators (1998) has highlighted various roles that parents play in a successful partnership. These roles include: role of communicators as bridges between school and communities, individual or group-based instructors, coordinators, assistants, and community coordinators. Such roles can result in strong ties between parents and schools. 
Various researchers have highlighted perspective of family school partnership from diverse scenarios like Blazer (2005) has exposed the benefits, barriers and strategies of family school partnership while reviewing home school partnership. Willemse et al. (2018) worked on FSP challenges for teacher education and found pre-service teachers are not well-prepared for FSP. Furthermore, Ferrara (2017)worked on "family engagement through the focus of National Standards for family school partnership" in which perspectives of pre-service teachers of secondary level were compared through pre-test and post-test. Moreover, Martin (2017) explored family school partnership at a university model school and concluded that teachers of UMS have similar problems for establishing and further maintaining FSP like other schools that are operated publically and privately. She concluded that to establish and sustain successful partnership; it is always desirable for all stakeholders to have a common viewpoint, similar family and socioeconomic background. Davies (2000) has come up with certain prerequisites that can work as foundation stones of FSP in any school like FSP depends on reciprocity of stakeholders. They should be respectful of race, language, ethnicity and qualification of its partners and always be ready to resolve the conflicts in discreet manner. Stakeholders should work on all factors that can hinder or boost FSP like modes and use of communication, volunteerism, power of decision, support and education level of the family and tactics to raise at home learning. Larrosa et al. (2019) worked on exploring "teachers and trainee teachers' beliefs about family school relationship". Trainee teachers were found to be more collaborative as compared to in service teachers and preschool teachers were more collaborative in their viewpoint as compared to primary school and trainee teachers.

Apart of above all, the United States Department of Education published a blueprint titled, "Partners in Education: A Dual Capacity- Building Framework for Family-School-Partnerships" for addressing the need of establishing and expanding a strong family school partnership across various districts of USA. Moreover, government of Australia with the help of Department of Education, Skills and Employment endorsed document titled, "Family School Partnership: A guide for schools and families" in 2008 to promote and guide partnership activities in schools. Again in Australia, Catholic Education Office wellbeing and Community Partnerships Unit, Melbourne developed an extensive document titled, "Leading Family School Partnership" which was intended to enable leaders of schools to be aware of and fortify their role as leader for operating an active family school partnerships. However, in Pakistan no such official documents has emerged yet which gives rise to need of presenting documents in form of guidebook for smooth and uniform running of FSP.

\section{Material and Methodology}

All the teachers, students of $10^{\text {th }}$ class and their parents were considered as the overall population of the study. By using multistage sampling technique, at $1^{\text {st }}$ stage 30 secondary schools(out of 350) schools, at $2^{\text {nd }}$ stage 120 teachers (out of total 2267 teachers), at $3^{\text {rd }}$ stage,300 parents were selected keeping in view the time constraints and limited financial resources of researcher. To find out perceptions of 
teachers and parents regarding family school partnership, two separate Likert type scales were developed under various themes. Scale for teachers had 27 items which were distributed under two themes and five levels ranging 1-5 with response title, Strongly Agree-Strongly Disagree. In this scale total15 statement were under the theme of "teachers' general perceptions regarding FSP" while remaining 12 statement were presented under the theme, "teachers' perceptions regarding role of family in FSP" for which scale set by Ferrara (2017) was used as a model

Parents' scale was presented under these four themes; "frequency of family involvement, frequency of academic assistance by family, challenges of family school partnership, roles and responsibilities". There were total four statements in each theme except in theme "challenges of FSP" which had five statements. All themes had five response levels. A translated version of Urdu was presented to parents for parents' ease and convenience in understanding the true nature of items. Both the scales were found valid as they measured what they supposed to measure.

As the study was survey based and descriptive in nature, therefore, for the analysis of scales, Mean and percentage methods were used.

\section{Results and Discussion}

Thematic Analysis of Teachers' Scale

Theme One: Teachers' perceptions regarding FSP

\begin{tabular}{ccccc}
\hline $\begin{array}{c}\text { S. } \\
\text { No. }\end{array}$ & Items & Highest $\%$ & Lowest $\%$ & $\begin{array}{c}\text { Mean } \\
\text { Score }\end{array}$ \\
\hline 1 & Central position of FSP & 86 & 8 & 4.25 \\
\hline 2 & Parent Teacher Organization & 72 & 19 & 3.83 \\
\hline 3 & Role of FSP & 86 & 11 & 4.13 \\
\hline 4 & Recognition of teachers & 76 & 9 & 3.85 \\
\hline 5 & Schedule of teachers & 55 & 39 & 2.84 \\
\hline 6 & Teacher training & 94 & 3 & 4.16 \\
\hline 7 & Academic success of students and & 94 & 2 & 4.52 \\
\hline 8 & FSP & 79 & 8 & 3.89 \\
\hline 9 & Use of new approaches for effective & FSP & 13 & 3.73 \\
\hline 10 & Teachers' role in decision making & 66 & 21 & 3.50 \\
\hline 11 & Community support for FSP & 58 & 3 & 4.18 \\
\hline 12 & Social climate for students and & 89 & 2 & 4.12 \\
\hline 13 & parents & 83 & 25 & 2.35 \\
\hline 14 & Collaborative service & 68 & 6 & 4.35 \\
\hline 15 & Improvement of students' & performance & 5 & 4.45 \\
\hline
\end{tabular}


Overall, $86 \%$ teachers were strongly agreed that in any school FSP has central position which cannot be denied. On the whole, $72 \%$ teachers were agreed that their school had an active and effective FSP in form of PARENT TEACHER ORGANIZATION and a negligible percentage of only 19\% had opposite opinion. It is to be believed strongly by $86 \%$ teachers that FSP is helpful in enabling teachers to be efficient and effective for students. $76 \%$ teachers were agreed that they should receive recognition from their school authorities and parents for sparing ample time for FSP activities out of their teaching workload.

It is to be strongly disagreed by $55 \%$ teachers that they have no time to involve parents in FSP in a useful manner. However, 94\% teachers demanded that they should be well trained for FSP and their schools should provide proper training to effectively handle and manage FSP program. 94\% teachers were strongly agreed that FSP has important role in academic success of students in school. It is to be strongly believed by $79 \%$ teachers that they focus on using novel and non-traditional approaches for the improvement of FSP. However, $66 \%$ teachers agreed that teachers have decision power regarding school activities and students in spite of parents' involvement in FSP.58\% teachers believed that community plays its role by supporting FSP practices. Overall, 89\% teachers believe that their school has best social climate for parents and their children in form of FSP practices and a conducive social environment is provided in schools to parents and students.

Nonetheless, in spite of all the efforts put forth by the teachers and school authorities for FSP, $83 \%$, teachers still agreed that FSP is collaborative venture in which all have to play their allotted role whether parents, teachers and school authorities.68\% teachers were found disagreed that there is no need of FSP for the improvement of academic performance of students. Total $94 \%$ teachers strongly believe that parent teacher meeting is crucial component of any FSP because through this they better find out their students' academic problems which hinder their bright performance. However, 95\% teachers strongly agreed that FSP is impractical without parents' constant support and assistance in form of their cooperation with teachers and school authorities.

A large majority of statements have mean score greater than 3:00 except only two statements which indicate strong agreed opinion of teachers towards the phenomenon of FSP

Theme Two: Teachers' perceptions regarding role of family in FSP

\begin{tabular}{ccccc}
\hline $\begin{array}{c}\text { Item } \\
\text { No. }\end{array}$ & Statement & Highest $\%$ & Lowest $\%$ & $\begin{array}{c}\text { Mean } \\
\text { Score }\end{array}$ \\
\hline 1 & Parents and homework & 45 & 20 & 3.30 \\
\hline 2 & Parents' training & 74 & 19 & 3.79 \\
\hline 3 & Parents' willingness & 46 & 43 & 3.03 \\
\hline 4 & Family: A supportive partner with & 67 & 3 & 3.85 \\
\hline 5 & Contact with parents for students' \\
problems & 74 & 3 & 3.94 \\
\hline
\end{tabular}




\begin{tabular}{ccccc}
\hline 6 & Follow up of students & 68 & 8 & 3.83 \\
\hline 7 & Benefit of teacher parent contact & 85 & 2 & 4.15 \\
\hline 8 & Parents' crucial role & 51 & 41 & 2.93 \\
\hline 9 & Open discussion by parents in PTMs & 89 & 7 & 4.32 \\
\hline 10 & Parents' avoiding behavior & 67 & 22 & 3.66 \\
\hline 11 & Mothers are more concerned & 60 & 32 & 3.23 \\
\hline 12 & Strengths of family & 73 & 12 & 3.73 \\
\hline
\end{tabular}

Overall, $45 \%$ teachers were agreed that parents should know the ways to assist their children at home while completing any home assignment. However, 74\% teachers suggest that if parents are trained then they can better assess their children at home. On the whole, $46 \%$ teachers strongly believe that parents are willing to be involved in social and academic matters of school through various social and financial contributions.

It is perception of $67 \%$ teachers that their schools consider family as vital partner of school: family is regarded as a key associate of school authorities. It is strongly believed by $74 \%$ teachers that usually they contact parents of teachers only when problematic situations arise by their children. However, overall $68 \%$ teachers also believe strongly that for constant follow up of students' performance they keep parents' groups engaged. Therefore, it is strongly believed by $85 \%$ teachers that when they are in contact with parents, they feel progression in students' performance.

Overall, 51\% teachers disagree that only family has to play its role in FSP rather than teachers and community. It is to be suggested by $89 \%$ teachers that there should be open discussion by the parents under parent teacher meeting which can help teachers to get open feedback by the parents.

On the whole, $67 \%$ complaint strongly those parents avoid to attend parent teacher meetings frequently. $60 \%$ teachers also strongly complaint that mothers are more concerned for their children as compared to fathers. While family is composite of both father and mother. Overall, 58\% teachers strongly agreed that family has strength to boost the success of their children which can be used by parents to push their children with help of teachers.

A large majority of statements have mean score greater than 3:00 except only one statement which indicate strong agreed opinion of teachers towards the phenomenon of FSP. 
Thematic Analysis of Parents' Scale

Theme One: Frequency of Family Involvement

Levels: Almost never, Once or twice a year, Every few months, Monthly, Weekly

\begin{tabular}{cccc}
\hline $\begin{array}{c}\text { S. } \\
\text { No. }\end{array}$ & Statement & Highest $\%$ & Lowest $\%$ \\
\hline 1 & Meeting with teachers & 27 & 5 \\
\hline 2 & $\begin{array}{c}\text { Contact with teachers through social media } \\
\text { and electronic modes of communication }\end{array}$ & 49 & 3 \\
\hline 3 & Involvement in fundraising & 33 & 19 \\
\hline 4 & Helping out in social and financial matters & 56 & 9 \\
\hline
\end{tabular}

Theme one reveals that $27 \%$ parents meet teachers of their children on monthly basis while only 5\% parents have met teachers almost never. $49 \%$ parents keep contact with teachers through calls and social media(facebook, twitter, whats app and emails) to get themselves updated about their children.43\% parents get themselves involved in fundraising activities for school on weekly basis so that they can generate funds for FSP activities.56\% parents also help school personally in dealing with social and financial matters of schools on weekly basis like help in getting furniture, help in electricity bills, giving donations to needy lower staff. On the other hand only $5 \%$ parents had never provided such services to school.

\section{Theme Two: Frequency f Academic Assistance By Family}

Levels: Almost never, Once in a while, Sometimes, Frequently, Almost all the time

\begin{tabular}{cccc}
\hline S. No. & Statement & Highest $\%$ & Lowest $\%$ \\
\hline 1 & $\begin{array}{c}\text { Conversation with child regarding } \\
\text { classwork and activities }\end{array}$ & 49 & 8 \\
\hline 2 & $\begin{array}{c}\text { Helping children in self-learning at } \\
\text { home }\end{array}$ & 43 & 6 \\
\hline 3 & $\begin{array}{c}\text { Provision of assistance to child about } \\
\text { content learning }\end{array}$ & 25 & 9 \\
\hline 4 & $\begin{array}{c}\text { Open discussion with child about } \\
\text { problematic matters in school }\end{array}$ & 35 & 7 \\
\hline
\end{tabular}

Overall, 49\% parents believe that they provide academic assistance to their children in form of talking with them about their school activities and school assignments on frequent basis, $8 \%$ parents converse with them almost all the time. However, parents do not assist children for self-learning as $43 \%$ belief that they almost never encouraged their children for self-learning at home without teachers' assistance. Assistance for content learning is provided by teachers but only $25 \%$ parents do this frequently, $9 \%$ parents do this almost all the time. There is open discussion by $35 \%$ parents with their children regarding academic and social problems faced by their children on frequent basis while $7 \%$ did almost never. 


\section{Theme Three: Challenges of family school partnership}

Levels: Not a problem at all, Small problem, Minor problem, Big problem, Great problem

S. No.

Statement

Highest $\%$

Lowest $\%$

\begin{tabular}{cccc}
\hline 1 & Lack of catering child care needs & 45 & 12 \\
\hline 2 & Parents' busy schedule & 45 & 6 \\
\hline 3 & Communication gap & 46 & 11 \\
\hline 4 & Child's own avoiding attitude & 37 & 12 \\
\hline 5 & Infrastructure & 92 & 2 \\
\hline
\end{tabular}

Overall, $45 \%$ parents had the belief that there is no lack of catering child care need in school as in their view this is a small problem which does not bother them to be involved in FSP activities. Only $12 \%$ parents take it as a big problem for them. On the whole, $45 \%$ parents admit that they have busy schedule which is cause of their lack of engagement in FSP activities like attending PTMs and annual parents' day on regular basis.46\% parents complaint that there is communication gap between school authorities, teachers and parents and they take it as a big problem. Because when there is lack of communication misunderstandings emerge.37\% parents take child's own avoiding attitude as not a problem. They deny the fact that their child does not insist them to attend meetings in which she has any doubts of reporting her complaints by the teachers. Lack of infrastructure is also not a big problem as perceived by $92 \%$ parents.

Theme Four: Perceived roles and responsibilities Levels: Always, Almost, Mostly, to some extent, Never

\begin{tabular}{cccc}
\hline S. No. & Statement & Highest $\%$ & Lowest $\%$ \\
\hline 1 & $\begin{array}{c}\text { Success of child: A collaborative } \\
\text { responsibility }\end{array}$ & 47 & 4 \\
\hline 2 & $\begin{array}{c}\text { Teacher: Sole responsible for child's } \\
\text { academic achievement }\end{array}$ & 43 & 3 \\
\hline 3 & Sharing of tasks and assignments & 48 & 2 \\
\hline 4 & FSP: A shared responsibility & 31 & 7 \\
\hline
\end{tabular}

Overall, $47 \%$ parents have the view that for the success of child, FSP is always a collaborative responsibility which should be prioritized by both parties, school and family.Therefore, $43 \%$ parents disagree that teacher is always a sole responsible for improved academic achievement of child.48\% parents agree that as FSP is shared venture ,therefore, teacher should always share task and responsibilities with them as well.31\% conclude that FSP is always a shared activity. Parents, school authorities and teachers all should play their allotted role. 


\section{Conclusion}

Family has a key role in overall development of children and definitely this role is played by parents with the help of school authorities and teachers. Therefore, a cohesive partnership between school and families is always desirable. Keeping in view this remarkable association of family and school, this survey was conducted to highlight the perceptions of both stakeholders, teachers and parents regarding Family School Partnership. It was found after analysis that a large majority of teachers as participants of the study were strongly convinced that importance of FSP is undoubtedly a core need of any school which is always been supportive in discussing students' academic, social and behavioral issues with their parents openly while furthermore convincing them for volunteer and charity services. Teachers of present study had collaborative approach like teachers of study by Larrosa et al. (2019) who also found teachers to be collaborative towards families. Parents of present study are also convinced that FSP always demand cooperation and collaboration. So, an alliance was evident in perceptions of parents and teachers. Parents and teachers furthermore claim that occasional and frequent meetings with both parties serve as a platform for improved collaboration and academic success of students. Result is congruent with study result by Martin (2017) whose participant parents also agreed that collaboration for successful FSP is need of time. It indicates that FSP coexist in schools which can be furthermore enhanced through various means like training of teachers as teachers of present study are well aware by the fact that FSP matters a lot but they complaint that there is lack of adequate training for engaging families in a meaningful manner. They feel the need of training programs to equip themselves to run FSP program and practices effectively and smoothly. Study result by Martin (2017) is in line with present study whose participant teachers also felt the need of professional training of teachers for FSP.Teachers of present study take family as partner who work with them active partners. Mapp and Kuttner (2013) also suggest teachers to be devoted to work as partners with families and in turn families should consider themselves as partners who work for smooth journey of their children. Parents of study by Martin (2017) also preferred to use electronic modes of communication and social media like parents of present study and regarded FSP as a shared responsibility.

A strong bond between family and school in form of FSP is key determinant of their child's success in school. Participation should have collaborative spirit whose purpose is to foster a culture of open communication, helping, generating resources, accepting roles and welcoming responsibilities in which both teachers and parents have to recognize each other's contribution. It is not sole responsibility of any one rather reciprocal one. Although teachers are veteran who can better communicate parents how to monitor their child's work at home and how to prepare him or her for self-learning. Now it is responsibility of school authorities to provide training opportunities to teachers for managing FSP practices like for maintaining outreach, making contact with media to publicize FSP activities as sports festivals, parents' day for parents' recognition for donation activities, for attending PTMs regularly and allocating budget. Universities and institutes of professional training for teachers should also play their role by offering such courses to prospective teachers which are 
about establishing and managing FSP to equip them for future jobs with the deep understanding of family school partnership. Parents should attend parent teacher meetings, book and sports festivals, exhibitions of students' projects, sponsor social gatherings, monitor child's learning at home and communicate well for being updated about their child's progress. 


\section{References}

American Association of School Administrators. (1998). Promoting Parent Involvement [Electronic version]. Leaders' edge, 2(2).

Blazer.C.(2005).The literature review on family involvement: The home-school partnership. Retrieved from http://drs.dadeschools.net

Bryan,J.B.(2005).Fostering educational resilience and achievement in urban schools through school-family community partnerships. Professional School of Counselling.8, 219-227.

Catholic Education Office Wellbeing \& Community Partnerships Unit. (2014). Leading family school partnerships. CEOM, East Melbourne

Collier, M., Keefe, E. B., \&Hirrel, L. A. (2015). Preparing Special Education Teachers to Collaborate With Families. School Community Journal, 25, 117-135

Davies, D. (2000). How to build partnerships that work. Principal, 80(1)

Department of Education, Employment and Workplace Relations. (2008). FamilySchool partnerships framework: A guide for schools and families. Australian Government

Desforges, C. \&Abouchar, A. (2003). The impact of Parental involvement, Parental Support and Family Education on Pupil Achievement: A Literature Review DFES Research Report 433.

Ferguson, D. (2004). Did You Know About the Difference Between "Parental Involvement" and "Family/ Community Linkages?" National Institute for Urban School Improvement. http:/ / www.inclusiveschools.org.

Ferrara, M.M. (2017).Understanding family engagement through the focus of the National Standards for family school partnership: Secondary pre service teachers' perspectives. School Community Journal, 2 (2).145-166

Haack, M.K. (2007).Parents' and teachers' beliefs about parental involvement in schooling. (Unpublished doctoral dissertation). Faculty of the Graduate College, College of Education and Human Sciences, University of Nebraska, Lincoln.

Henderson, A.T. and Berla. (1994). The Evidence Continues To Grow: Parent Involvement Improves Students. Columbia, MD: National Committee for Citizens Education.

Ahmad, I. Muzaffar, M \& Javaid, M. A. (2016). School Environment and Political Awareness at Secondary Level: A Case Study of Pakistan, Pakistan Journal of Social Sciences, Vol 36 Issue, 991-1000 
Kim,M. E., Coutts, M. J., Holmes, S. R., Sheridan, S. M., Ransom, K. A., Sjuts, T. M., \&Rispoli, K. M. (2012). Parent involvement and family-school partnerships: Examining the content, processes, and outcomes of structural versus relationship-based approaches (CYFS Working Paper No. 2012-6). Nebraska Centre for Research on Children, Youth, Families and Schools, cyfs.unl.edu

Larrosa, S. P., Richards. A., Rodríguez, S, A. M. \& Soriano, L.G. (2019).Teachers and trainee teachers' beliefs about family-school relationships. Aula Abierta,48(1).5966.doi:10.17811/rifie.48.1.2019.59-66

Leon, L. (2003). Parents and Secondary Schools. Principal Leadership, 4 (4). 32-37.

Lonsdale, M \& Australian Council for Educational Research (ACER). (2008). Schools First: Final Report, http://www.schoolsfirst.edu.au/docs/schools-first-evidencebase-acer.pdf

Mandarakas, M. (2014).Teachers and parent-school engagement: international perspectives on teachers' preparation for and views about working with parents. Global Studies of Childhood,4 (1).21-27.

Mapp, K. L., \&Kuttner, P. J. (2013). Partners in education: A dual capacity-building framework for family-school partnerships. Austin TX:http://www2.ed.gov/documents/family-community/partnerseducation.pdf

Martin, P.L. (2017).An exploration of family-school partnerships at a university-model school. (Unpublished doctoral dissertation). Department of Counselling, Educational Leadership, Educational and School Psychology, Wichita State University.

National Parent Teacher Association (PTA). (2012). National standards for family-school partnerships. http://www.pta.org/nationalstandards

Semke, C. A., \& Sheridan, S. M. (2011). Family-school connections in rural educational settings: A systematic review of the empirical literature. National Center for Research on Rural Education, 1-29.

Willemse, M. T. Thompson, I. Vanderlinde, R. \& Mutton. T. (2018). Family school partnership: A challenge for teacher education. Journal of Education for Teaching, 44 (3).252-257.doi:10.1080/02607476.2018.1465545 